Article

\title{
Parliamentarizing a Politicized Policy: Understanding the Involvement of the European Parliament in UN Climate Negotiations
}

\author{
Tom Delreux ${ }^{1, *}$ and Charlotte Burns ${ }^{2}$ \\ ${ }^{1}$ Institut de Sciences Politiques Louvain-Europe, UCLouvain, 1348 Louvain-la-Neuve, Belgium; \\ E-Mail: tom.delreux@uclouvain.be \\ 2 Department of Politics and International Relations, University of Sheffield, Sheffield, S10 2TU, UK; \\ E-Mail: charlotte.burns@sheffield.ac.uk \\ * Corresponding author
}

Submitted: 16 March 2019 | Accepted: 6 June 2019 | Published: 27 September 2019

\begin{abstract}
Climate change is a central topic of concern for EU international diplomacy and is the site of increased politicization globally. Concomitantly, a parallel process of parliamentarization of the EU has unfolded. Whilst the European Parliament (EP) has enjoyed significant powers in internal policy-making on climate change, since the entry into force of the Lisbon Treaty in 2009 the EP has gained the right to veto the EU's ratification of international (climate change) agreements. This development raises questions about our understanding of the EP as an actor in international climate diplomacy that this article addresses through the following research question: What impact have the increased powers of the EP had on its involvement in UN climate diplomacy? We analyze the EP's evolving role in international climate diplomacy through an evaluation of its policy preferences prior to international climate conferences (COPs) and its activities during those meetings. We find evidence that the EP's preferences have become more moderate over time, and that it is also more active at COPs and increasingly engaged with a range of more important actors. However, we find little evidence that the EP's involvement in international negotiations is significantly different when it holds a veto power, which we attribute to a willingness to depoliticize internal EU climate negotiations to secure policy gains at the international level.
\end{abstract}

\section{Keywords}

climate change; climate diplomacy; Conference of the Parties; European Parliament; European Union; parliamentarization; parliamentary diplomacy; United Nations Framework Convention on Climate Change

\section{Issue}

This article is part of the issue "Out of the Shadows, Into the Limelight: Parliaments and Politicisation", edited by Christine Neuhold (Maastricht University, The Netherlands) and Guri Rosén (University of Oslo, Norway).

(C) 2019 by the authors; licensee Cogitatio (Lisbon, Portugal). This article is licensed under a Creative Commons Attribution 4.0 International License (CC BY).

\section{Introduction}

The European Parliament (EP) has gradually become an important and influential actor in shaping the EU'S internal climate policies. Acting as an environmental champion, it has pushed the EU's green agenda and strengthened its legislation (Burns, 2013; Judge, 1992). Interestingly, it has had historically limited formal powers in the external policy-making arena of international climate diplomacy, a highly politicized policy field where the EU has profiled itself as a leader (Burns, 2017; Burns \& Carter, 2010; Delreux, 2011). However, whilst the formal powers of the EP have grown with the entry into force of the Lisbon Treaty in 2009 there has been limited attention paid to the parliamentarization of the EU's international climate diplomacy (Biedenkopf, 2015, being a notable exception). For example, a recent thematic issue of this journal on the 2015 Paris climate conference has no specific discussion of the EP (Hovi \& Skodvin, 2016) and an article focused upon the EU's position (Schreurs, 
2016) makes only passing reference to the Parliament. This article addresses this lacuna in our knowledge by investigating the EP's involvement in international climate diplomacy through a systematic evaluation of its expressed policy preferences prior to United Nations Framework Convention on Climate Change (UNFCCC) Conference of the Parties' (COP) meetings and its activities during those COPs. In doing so we contribute to the literatures on the parliamentarization of external EU policy-making, the rational choice institutionalist scholarship on the empowerment of the $E P$, works on international climate diplomacy and we contribute to a better understanding of how the politicization of climate change at the international level has shaped the EP's positioning on the issue.

The Lisbon Treaty introduced the right for the EP to veto the ratification of most international agreements, including climate treaties. The EP has used its ex post veto power to reject the Anti-Counterfeiting Trade Agreement (ACTA) and the Society for Worldwide Interbank Financial Telecommunications (SWIFT) Agreement (Monar, 2010; Ripoll Servent, 2014). Given this new power we ask: What impact have the increased powers of the EP had on its involvement in UN climate diplomacy? We examine that involvement by analyzing the activities of the EP before (ex ante) and during (ad locum) international climate negotiations. Before the negotiations, the EP adopts resolutions in which it signals its preferred outcomes for the international negotiations. During the negotiations, a delegation of Members of the EP (MEPs) attends the negotiations and conducts its own diplomatic activities. We develop two expectations on the EP's ex ante and ad locum involvement. First, we anticipate that the EP's involvement has evolved over time, in the sense that: (a) the EP's expressed preferences have converged with those of the Council; and (b) it has become diplomatically more active. Second, we expect that both the ex ante and the ad locum involvement depend on whether the EP has a veto power. Assuming that the ex post veto will cast its shadow on ex ante and ad locum involvement, we envisage that the EP's preferences will be closer to the Council's and the EP delegation will be more active when the intended outcome of the international negotiations is a legally binding treaty (where the EP's ex post consent is required) than when the intended outcome is not a treaty (and where there is no consent requirement). Overall, we suggest that the increased politicization of climate change around such legally binding treaties is a crucial part of the explanation for the EP's conduct.

To develop our argument, we examine the Parliament's involvement in the EU's climate diplomacy at the annual COPs of the UNFCCC between 2007 and 2017. In the following Section 2 we review the literature on the EP's powers and involvement in the EU's external relations, before deriving four expectations. We then analyze the resolutions adopted by the EP before the international negotiations (Section 3 ) and the activities of the EP delegation during the negotiations (Section 4).
We conclude in Section 5 that whilst there is evidence that the EP has converged with the Council over time it has simultaneously become more active at COPs and increasingly engaged with a range of more important actors. We find limited evidence that the EP's behaviour is different when it holds a veto power.

\section{The EP's Empowerment in EU External Relations and Involvement in International Negotiations}

In 2009 the Lisbon Treaty introduced two key powers for the EP in the field of external affairs that have contributed to the parliamentarization of EU climate diplomacy, and challenged the traditional executive dominance of this policy area. First, the EP's consent is now required for the EU's ratification of most legally binding international agreements, i.e., treaties (EU, 2012, Art. 218§6). Therefore, the EP has no veto power over international negotiations that do not have treaty status, such as 'normal' COP decisions. Since 2009, the consent procedure applies to agreements in fields covered by the ordinary legislative procedure, including climate change. Prior to the entry into force of the Lisbon Treaty, the Parliament was only involved through consultation in the ratification process, and therefore did not enjoy an ex post veto power (Delreux, 2011).

Second, the EP 'shall be immediately and fully informed at all stages of the procedure' (EU, 2012, Art. 218§10). As the Treaty does not specify how the EP should be informed, a number of Interinstitutional Agreements (IIAs) have been adopted in order to clarify inter-institutional relations, most notably by requiring that the EP be informed and consulted on all international treaty negotiations (Thym, 2008). The EP's information right is achieved through giving access to documents about the negotiations and through allowing MEPs to attend international meetings in a so-called 'EP delegation' (Urban, 2018). However, there is no formal role for the EP in drafting the EU position for international negotiations, which remains the prerogative of the Council. Nevertheless in a broad range of external policy fields, the EP regularly adopts resolutions in order to put issues on the agenda (Ripoll Servent, 2018), to influence the official EU position (Jančić, 2016) and to signal its preferences-and the range of agreements that will be acceptable in the ratification stage-to the Council and the Commission, as well as to third actors.

Although the EP's most straightforward formal power is limited to an ex post veto power, the EP has long been 'rather successful in maximizing its influence through informal decision-making' (Van Hecke \& Wolfs, 2015, p. 303), both in the stages of ex ante and ad locum involvement. Interestingly, the rising parliamentarization of the EU's external relations has not been strongly opposed by EU negotiators. The recognition of the EP by the other institutions has been driven by both legitimacy concerns (Rosén, 2015) and the wish to strengthen the EU's negotiation position at the international level (Rosén, 2016). 
This discussion leads us to expect that the empowerment of the EP will have two types of effect on its ex ante and ad locum involvement in international climate negotiations: a changing involvement over time; and an amplified impact in the context of COPs where the consent procedure applies for the ratification of an international climate treaty.

A first set of expectations is that the increased powers of the EP will make the EP's stated policy preferences less ambitious and its involvement more active over time. Several studies suggest that the empowerment of the EP has coincided with growing political efforts to increase its international prestige and visibility (Raffaelli, 2013; Stavridis \& Irrera, 2015) and with more influence on the EU's external policies, both in CFSP (Riddervold \& Rosén, 2015; Rosén \& Raube, 2018) and in trade (Meissner, 2016; Van den Putte, De Ville, \& Orbie, 2015). We anticipate that the EP's expanding powers and increasing prestige manifest themselves in its involvement before and during COP negotiations.

Regarding the content of the resolutions and the EP's ex ante involvement, studies on the evolution of the EP in internal EU environmental policy-making have demonstrated that the policy positions adopted by the EP become more moderate once the EP has secured increases in power (Burns, Carter, Davies, \& Worsfold, 2013). Analyzing the EP's amendments over different policymaking procedures and over time Burns and Carter (2010; also see Burns et al., 2013) find that as the EP's powers increased through the extension of the ordinary legislative procedure the environmental ambition of the EP's amendments declined, but the Parliament's success in securing the adoption of its amendments increased. There are a number of reasons for this development. First, as the EP's powers have increased it has become more able to secure its policy preferences. A standard tactic used by the EP when the institution had more limited legislative influence was to adopt highly ambitious amendments knowing they were unlikely to be accepted by the Council. The purpose of such amendments varied: it could be to express a policy preference and shape future agendas; or they could serve as an opening gambit in a legislative negotiation in which the EP would be prepared to weaken its demand as the process unfolded (Burns \& Carter, 2010). The advent of the ordinary legislative procedure and the EP's ability to reject legislation has made this behaviour less relevant. In addition, the Council and EP have much greater informal and formal contact with each other and can discuss their preferences more openly. There is also scope for anticipatory compliance on the part of the Council and Commission where they too might moderate their positions to accommodate the EP's preferences (Ripoll Servent, 2013, 2018). We expect that this general trend of convergence will also apply to external climate policy, as a result of which the EP is likely to adopt positions that are more similar to the official EU position determined by the Council, which in turn may also be taking into account the likely policy positions of the EP and amending its own position, especially where the EP has a veto. This trend is likely to be reinforced by the EP's wish to be recognized as a significant diplomatic actor. This leads us to expect that the EP's stated preferences are more likely to be further away from the Council when it has less power, and that the Council and EP preferences converge when the EP has greater power and responsibility in the field of external relations. Hence, we expect that:

E1a. The ex ante expressed policy positions of the EP will converge with the Council's positions over time.

The EP's empowerment is also likely to affect the EP's ad locum involvement, i.e., the activities of the MEPs attending the international negotiations, over time. We expect that it will increase the level of activity of the EP delegation attending the COPs and that the number of activities by MEPs sur place will grow when the EP has acquired more powers. Additionally, the nature of the activities and the actors to whom the EP delegation reaches out is likely to change. We expect the EP delegation to conduct more diplomatic activities with third actors who really matter in international negotiations, i.e., governmental representatives. Hence, we expect that:

E1b. The number of activities of the EP delegation will grow over time and the nature of its interlocutors will change.

A second set of expectations is that the anticipated effects discussed above are amplified when the intended outcome of a COP is legally binding. This distinction between legally binding and non-legally binding outcomes of COPs matters as the EP only has formal ex post veto power on legally binding outcomes. Of the 11 COPs falling in the scope of our study, three were expected to lead to a legally binding outcome:

- COP 15 (Copenhagen, 2009): although COP 15 did not result in a treaty but only an 'accord', it was reasonable to expect that the consent procedure would be applicable to the Copenhagen outcome as a legally binding outcome was expected in the run-up to the COP (Earth Negotiations Bulletin, 2015);

- COP 18 (Doha, 2012): resulted in the 'Doha Amendment', a treaty establishing the second commitment period of the Kyoto Protocol. The Council adopted a decision on the ratification of the Doha Amendment in July 2015 after having received the consent of the EP in June 2015;

- COP 21 (Paris, 2015): where the Paris Agreement was agreed. The Paris Agreement was ratified by the Council in October 2016, one day after having received the EP's consent. While we recognize the difference between the substantive scope of the Doha Amendment and the Paris Agreement, both 
COP outcomes are legally binding, which makes it likely that the 'shadow of the consent procedure' affected the EP involvement.

One reason for this expectation relates to the politicization of the wider climate change agenda. Climate change has become increasingly politicized in many parts of the world, especially in the US (McCright \& Dunlap, 2011). The politicization of climate change internationally generated more polarization on the issue (De Wilde, 2011), which has had paradoxical effects. In order to secure support for the climate agenda, one reaction has been to seek to depoliticize the issue by fostering social consensus and public engagement (Pepermans \& Maeseele, 2016). In the EU, the issue of climate change has generally led to less polarization than in the US and other states such as Australia and Canada, nevertheless the rise of right-wing euro-sceptic parties that tend to be climate-sceptic has challenged the broad consensus (Carter, 2018). When a COP is expected to lead to a binding treaty, we therefore expect a higher level of politicization and a greater scope for disagreement at the international level, which puts more pressure upon the EU institutions to present a united front to secure EU policy preferences. In other words, politicization of climate change internationally leads to moves to depoliticize the issue across the EU's institutions. Hence, we expect that:

E2a. The shadow of consent is likely to lead to increased convergence between the EP's preferences and those of the Council for COPs that intend to produce a climate treaty.

Regarding ad locum involvement, the backwards shadow that the Parliament's veto can cast along the policymaking process may lead other EU actors to engage in anticipatory compliance in order to avoid the likelihood of the EP exercising its veto (Dür, 2006; Ripoll Servent, 2014). The Parliament has rarely used its veto and is most likely to do so either as a matter of principle (to remind the Council that it enjoys such powers and should not be ignored) or because its preferences significantly diverge from those of the Council. Both of these conditions pertained in the case of the ACTA and SWIFT vetoes. The EP felt it had been excluded from discussions so was prepared to use its veto to remind the Council that it was a key institutional player that could not be ignored (Monar, 2010; Ripoll Servent, 2014). Moreover, in the case of SWIFT the EP was concerned about the implications of the agreement for EU citizens and their data and in the case of ACTA it was concerned over privacy and internet freedom. In both cases the agreements were designed to establish new international regulatory regimes that had direct implications for EU citizens and their freedom and personal data. By contrast, when it comes to international climate diplomacy, the international climate regime has been in place since 1997 and the Council and EP are both committed to international climate policy and share similar goals. It consequently seems unlikely in this case that the EP's and Council's preferences would be so far apart that the EP would be prepared to reject EU ratification of an international climate treaty that the Council has accepted. It is possible, and more likely, that the EP would be prepared to reject a climate treaty if it felt that its prerogatives and signals have been ignored by the other EU institutions. Therefore, in order to avoid the exercise of an ex post veto, the Council and the Commission have an incentive to involve the EP during the negotiations (Biedenkopf, 2015; Monar, 2010; Onderco, 2018). This includes, on the one hand, organizing more direct contacts between the EU negotiators and the EP delegation, whereby the EU negotiators can transmit the pressures from the international negotiators to the EU's veto players who do not experience these pressures directly (Delreux, 2011), and, on the other hand, allowing the EP delegation to reach out to more actors, and notably to executive actors from third parties.

Similarly, in COPs where the outcome will be subject to the consent procedure, we also expect an intensification of the number of briefings from the Commission and the Council to the EP delegation towards the end of the two-week COP meeting. It is at the end of the negotiations that the EU negotiators will be forced to make concessions that might be difficult to accept for the vetoplayers. Hence, the EU negotiators will have the incentive to involve the EP delegation at that moment, in order to check whether certain concessions are acceptable, to make sure that the EP understands the difficulties faced by the EU negotiators, and ultimately to assure the acceptance of the final deal by the EP (Delreux \& Kerremans, 2010). Consequently:

E2b. The shadow of consent is likely to affect the number, nature, and intensity of the EP's activities in its ad locum involvement.

\section{Ex ante Involvement: EP Resolutions}

In order to determine the EP's preferences and their proximity to the Council we reviewed all EP resolutions and Council conclusions adopted prior to the COPs from 2007 to 2017 (the EP did not adopt a resolution in 2008 for COP 14 in Poznan). The COPs are typically held in November or December. The EP resolutions are debated and drafted in parallel with the Council developing its position but the EP tends to formally adopt its opinion a month ahead of the Council. We coded the resolutions and conclusions allowing key themes to emerge from the text. Hence, all the EP resolutions and Council conclusions were read through to determine the themes emerging from the text. Those themes were listed and then the documents were uploaded to a qualitative comparative software tool. The software was used to carry out a word count analysis, to find key phrases associated with the themes identified and to determine if any other 
key phrases emerged from the documents that the initial analysis had missed or overstated. Then each document was coded line by line to see whether and how key phrases were used. It is important to note that the number of times a phrase is used is only one indicator as a key theme can be mentioned only once whilst nevertheless still being important.

Figure 1 indicates nine core themes, the number of times they are mentioned by both institutions, and the relative attention the Council and the EP attach to each theme. Hence, Figure 1 allows a comparison between the EP and the Council in absolute terms-and an intrainstitutional comparison of EP resolutions and Council conclusions in relative terms. It shows that, in relative terms, the Council conclusions pay more attention to mitigation than the EP resolutions, whereas forestry, technology and transport are mentioned more frequently in EP resolutions than in Council conclusions. Figure 1 also indicates that the EP generally tends to mention the issues it cares about more than the Council-reflecting the fact that the EP's resolutions generally tend to be longer and less focused. Council resolutions are more legalistic and tightly framed. For instance, prior to the Bali COP in 2007, the Parliament chose to emphasize 'the moral obligation on industrialized countries to provide increased financial and capacity building support for risk reduction and adaptation to climate change' (EP, 2007), which is the kind of language that the Council typically eschews and certainly this statement of morality is not mirrored in any of the Council conclusions.

Hence, a first kind of difference that emerges between the Council and Parliament concerns the way in which topics are discussed. For example, on climate finance, an on-going issue in climate change diplomacy, the EP has consistently called for any climate finance pro- vided by the EU to be additional to official development assistance (ODA). The EP resolution and the Council conclusions ahead of the Copenhagen Conference reveal a significant difference between the EP and Council in language and positioning (see Table 1 ). The Council calls for all ODA to incorporate climate change considerations and for synergies to be sought between climate change and ODA goals, which could undermine the pursuit of genuine additionality in ODA as called for by the EP.

A second kind of difference is that, in contrast to the Council, the EP makes several calls for EU leadership and unity. Following COP 15 in Copenhagen, which was largely regarded as a failure for the EU, the EP identified the lack of EU unity as a reason for that failed leadership and urged the Council to speak with 'one voice' (EP, 2010a). EU unity became a key theme for the EP from 2009-2015 (EP, 2009, 2010b, 2011, 2012, 2013, 2014, 2015), but it disappeared from the resolutions for the 2016 Marrakech and 2017 Bonn COPs (EP, 2016, 2017). This finding suggests that the 'one voice' rhetorical device was used to shore up a united EU front in the run up to a COP intended to result in a legal treaty (COP 21 in Paris), but since then has no longer been regarded as necessary. Another theme that appears in EP resolutions but not in Council conclusions is the Parliament's call to be included in the daily EU coordination meetings during the COPs - a request that has yet to be accepted. However, a shift in wording appeared in 2015, the year of the Paris COP 21 that led to an international agreement, where the EP states that 'as it will also need to give its consent to any international agreement that it needs to be well integrated into the EU delegation' and 'expects therefore to be allowed to attend EU coordination meetings in Paris' (EP, 2015). Similar wording is used in the resolutions for the Marrakech (EP, 2016) and Bonn (EP, 2017) COPs. Here

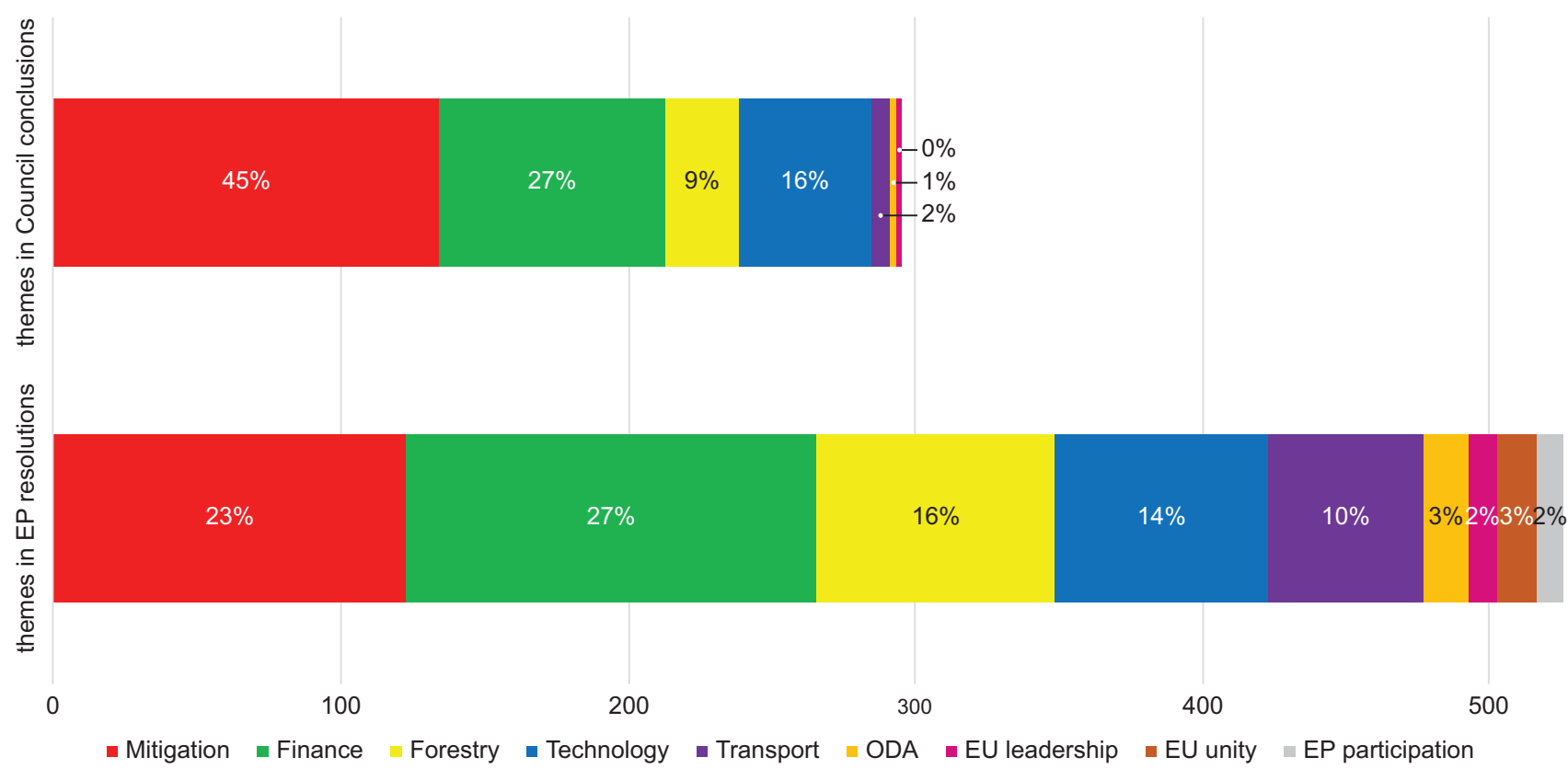

Figure 1. Core themes mentioned in Council conclusions and EP resolutions prior to the COP. 
Table 1. Positions on Climate Finance in EP and Council Resolutions in preparation of COP 15 in Copenhagen.

\begin{tabular}{ll}
\hline EP & Council \\
\hline $\begin{array}{l}\text { Insists that such commitments to provide for the required } \\
\text { predictable financial support for climate change }\end{array}$ & $\begin{array}{l}\text { STRESSES that all ODA expenditure should take climate } \\
\text { considerations into account with a view to making it } \\
\text { mitigation and adaptation in the context of the UNFCCC }\end{array}$ \\
$\begin{array}{l}\text { climate-proof; EMPHASISES that synergies in the } \\
\text { implementation of international climate finance and other }\end{array}$ \\
from annual budgetary procedures in the Member States; & $\begin{array}{l}\text { assistance in developing countries should be used as } \\
\text { much as possible, that the experience of existing }\end{array}$ \\
recalls that the resources should be distributed not as & $\begin{array}{l}\text { institutions, including multilateral and bilateral } \\
\text { concessional loans, but as grants; recalls the }\end{array}$ \\
already-existing commitments, aimed at achieving ODA & $\begin{array}{l}\text { developing countries should be used and the agreed } \\
\text { principles of aid effectiveness should be applied. }\end{array}$
\end{tabular}

Sources: EP (2009) and Council of the EU (2009).

we see a shift from a request to be included in coordination meetings to an expectation from the Parliament that given its legal role that it will be included.

Turning to the evolution of the proximity between the EP and the Council preferences, our analysis reveals an increasing similarity between the EP's and Council's positions. This is particularly the case for the mitigation theme. The positions on the other core themes are also largely similar, but are characterized by differences in tone and framing.

For example, on forestry, whilst the EP and Council both make the link between financing and combatting deforestation, the EP's resolutions are different in tone. Ahead of COP 21 the EP called on the EU to scale up international finance to combat deforestation (EP, 2015), whereas the Council does not use such wording and is mainly concerned with monitoring and verification (Council of the EU, 2015). Both institutions pay less attention to forestry from 2013 onwards with the Council failing to mention it from then on.

Likewise, on technology, because of the central role of technology in the clean development mechanism, much of the difference between the EP and Council stems from the association with finance and development, and the on-going development of renewables. In its Copenhagen resolution the EP was keen to ensure that developed countries do not use offsets instead of transferring technology to poorer countries (EP, 2009). The EP also called upon the EU ahead of COP 16 in Cancun (2010), to establish a leadership position in its own investment in clean technologies to set a good example for others (EP, 2010b). Prior to Durban (2011) the EP called for investment in 'appropriate technologies' (EP, 2011) and in its Paris resolution (2015) called for the removal of subsidies for fossil-fuel based technologies (EP, 2015). The Council though tends to emphasize national measures to encourage technology deployment and noted in its Poznan (2008) resolution that the EU supports the establishment of carbon capture and storage demonstration projects (Council of the EU, 2008). Across all these core themes-finance, forestry, technologythe two share broad policy preferences and the princi- pal differences between the EP and Council tend to be less about substance but more about framing with the EP pushing the Council-and thus the EU as an international actor - to be more ambitious and to take a leadership role.

When it comes to mitigation and targets the EP and Council were initially further apart and the EP has converged more obviously with the Council. From 2007 to 2013, although they were agreed on the overall direction of policy, there was a discrepancy in the targets they advocated. The Council committed to a $30 \%$ reduction in greenhouse gas emissions if other UNFCCC participants agree to the same target, by contrast the EP called for 30\% without conditions. However, from 2013 onwards the institutions' expressed preferences on targets became identical.

Generally speaking then for the period 2007-2017 the expressed policy positions of the two institutions have been fairly consistent, especially on the most important core theme of mitigation since the failure to achieve a treaty at Copenhagen. Hence, we find some evidence (particularly on mitigation) that the EP's positions converge with the Council's over time and that the former become more moderate (E1a). However, there is no particular shift in at COPs 15, 18 and 21 when the shadow of consent was present (E2a).

\section{Ad Locum Involvement: EP Delegations}

The EP has sent a delegation to every COP of the UNFCCC since the early 1990s. The EP delegation generally attends the second week of the COP. In the period under study, the EP delegation varied between 11 and 28 members, apart from the politicized outlier case COP 15 with 48 MEPs attending. In most cases, all political groups have at least one MEP in the delegation. The MEPs are accompanied by EP staff, mostly from the secretariat of the EP Committee on Environment, Public Health and Food Safety and EP Committee on Industry, Research and Energy, and the EP's Directorate-General for Communication, by an agent per political group, and sometimes by assistants to an individual MEP. During 
the COPs, the EP delegation holds meetings with EU actors who participate in the multilateral negotiations and with non-EU actors (our analysis is based on the 'summary notes' or 'mission reports' detailing the activities of the EP delegation, including a precise hour-by-hour programme). The meetings with the EU negotiators take the form of briefings. The number of briefings with the EU negotiators-Commission, Council Presidency, lead negotiator-is presented in Figure 2. As MEPs do not have direct access to most of the negotiation rooms as they are not allowed to participate in the daily EU coordination meetings (see above), these briefings are of crucial importance for them to get up-to-date about the developments in the COP negotiations.

Although the trend is neither systematic nor linear, the EP delegation now receives more briefings from the EU negotiators than a decade ago (E1b). By contrast, we do not find strong evidence supporting the expectation E2b that more briefings are organized when the COP's outcome is intended to be legally binding. On the one hand, indicating support for our 'shadow of consent' expectation, most briefings were indeed organized at COP 21 (which resulted in a legally binding outcome) and there were also more briefings at COP 15 than at the preceding and subsequent COPs. On the other hand, suggesting a rejection of the expectation, the number of briefings at COP 21 rather fits within the growing number of briefings over time than within a pattern related to the degree to which the outcome is binding. Moreover, we do not see a higher number of briefings at COP 18 (although the Doha Amendment was legally binding). Also, COP 17, with a high number of briefings but without a legally binding outcome, challenges the expectation.

We also expected that the number of briefings would intensify towards the end of a COP meeting in case that
COP meeting was intended to result in a legally binding agreement (E2b). Figure 3 presents the number of briefings per day at each COP. For a confirmation of our expectation, we should observe a pattern with an intensification of the number of briefings towards the end of COPs 15,18 and 21 than in other COPs. Yet, the empirical data do not provide evidence for this expectation.

Instead, what we see since COP 17 is an emerging standard practice of organizing one or two briefings a day. Particularly at COP 20 in Lima (2014), a practice seems to be institutionalized to organize two briefings per day. After the daily EU coordination meeting that takes place in the morning, the rotating Presidency briefs the MEPs on the state of play in the negotiations and on the discussions in the EU coordination meeting (which was chaired by the Presidency). The second briefing is given by the Commission. It takes place in the evening to discuss the progress made during the day (and sometimes the prospect of the upcoming all-night negotiations). Evidently, the contacts between the MEPs and the EU negotiators are not limited to these reported briefings. Informal talks with representatives of the Commission, the Presidency and other member states undoubtedly occur in the corridors of the negotiations and particularly in the 'EU Pavilion', where the EU's offices are housed during the COP (and where the EP has its own office since COP 15).

The second kind of interlocutors of the EP delegation sur place are non-EU actors. Figure 4 presents the evolution in the number of ad locum outreach activities by the EP delegation. Examining with whom the EP delegation meets at the COP venues reveals a number of interesting observations.

First, with the exception of COP 18, the number of meetings with representatives of international or-

12

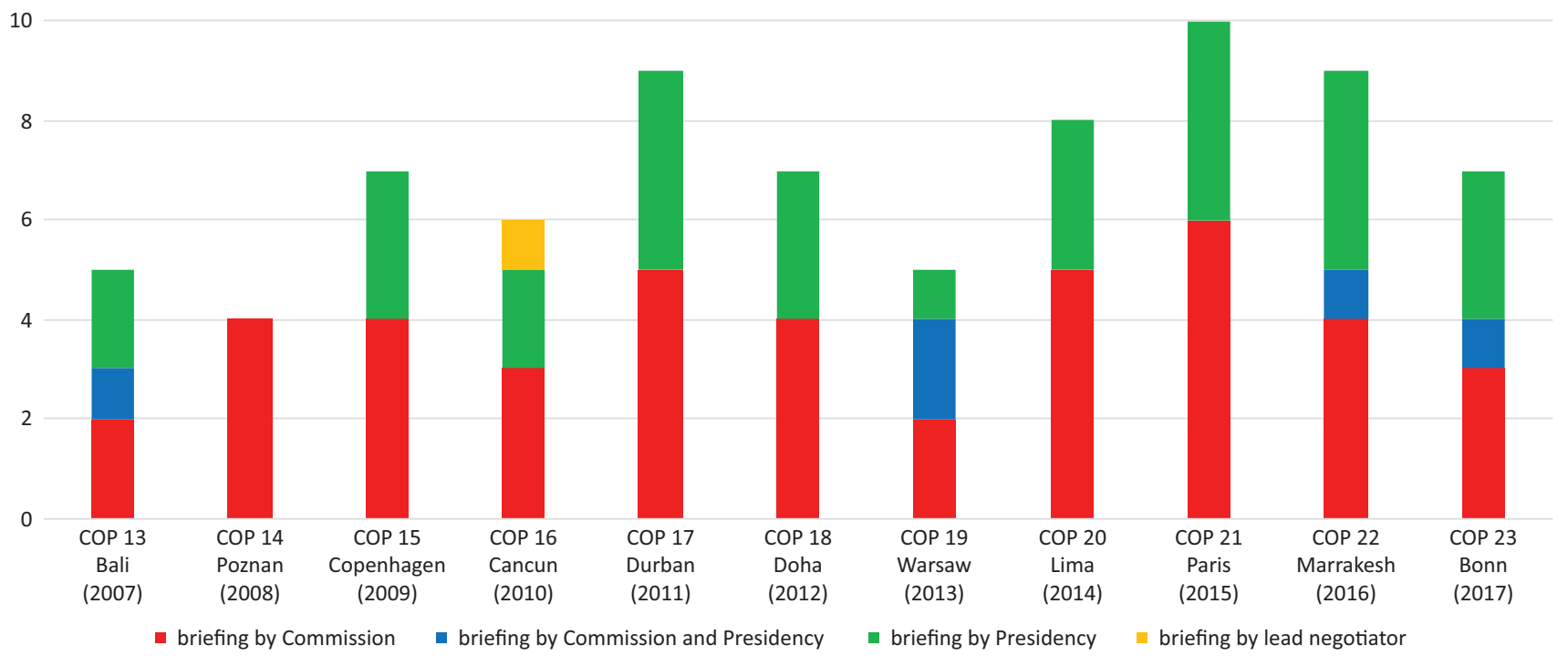

Figure 2. Number of briefings with EU negotiators. 
day 1 day 2 day 3 day 4 day 5 day 6 day 7 day 8 day 9 day 10 day 11 day 12 day 13

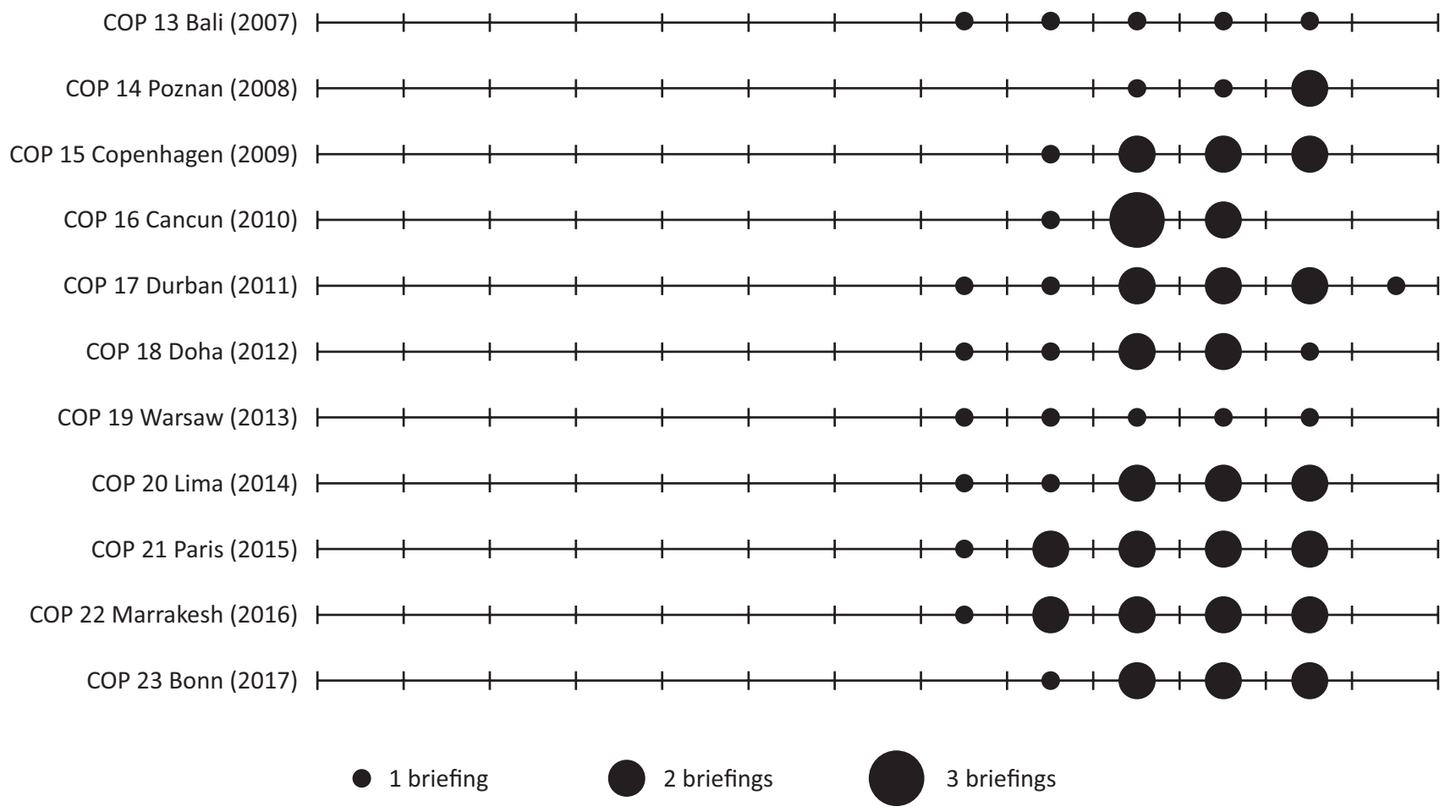

Figure 3. Distribution of briefings with EU negotiators per day per COP.

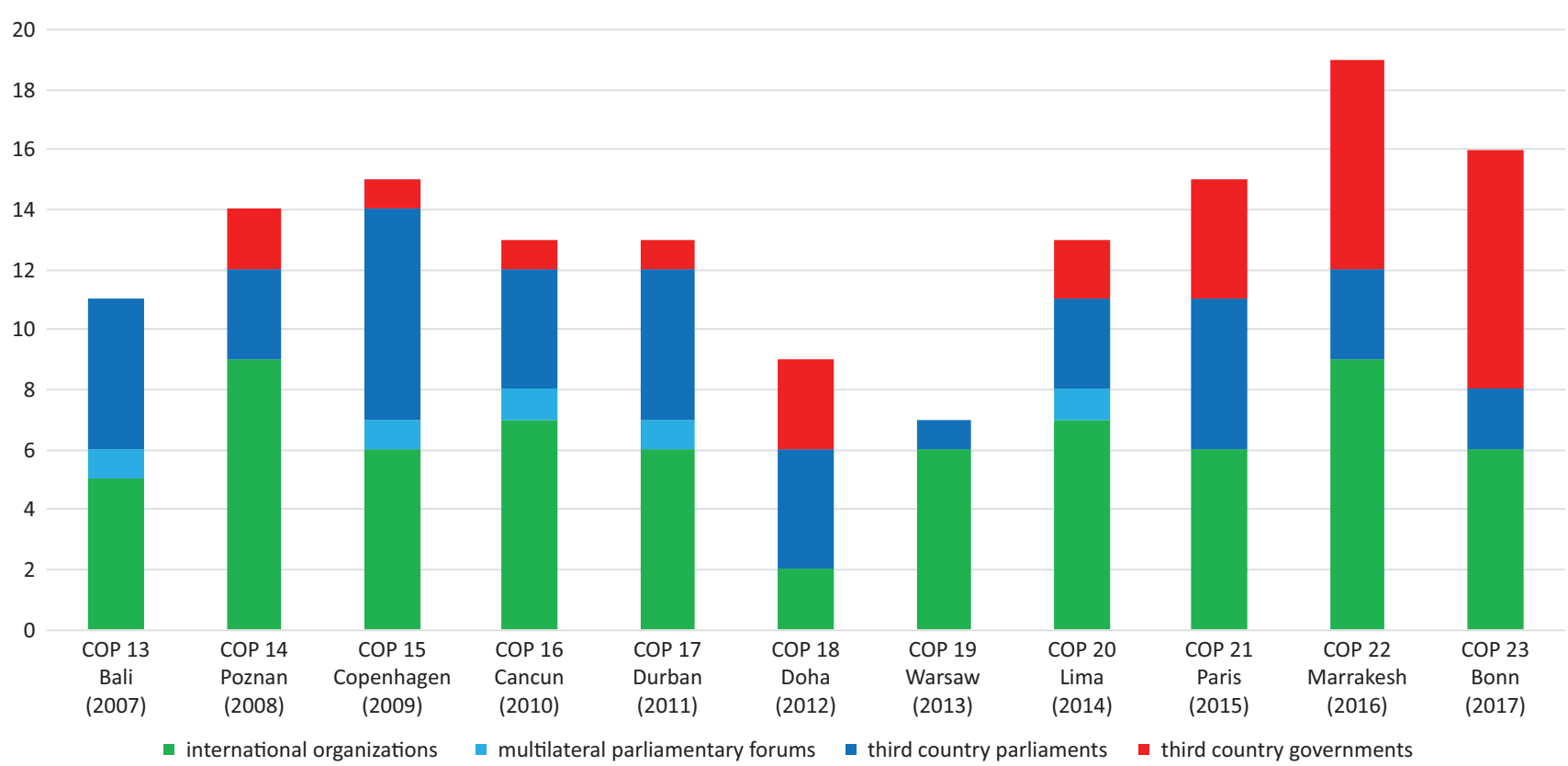

Figure 4. Number of meetings with non-EU actors.

ganizations has been relatively stable. On average, approximately half of the EP delegation's meetings with non-EU actors are with representatives of intergovernmental organizations that deal with climaterelated issues, both within the UN framework (e.g., United Nations Environment Programme, Food and Agriculture Organization, United Nations Development Programme, Global Environment Facility, International Energy Agency, World Health Organization, International
Civil Aviation Organization, International Maritime Organization) and outside the UN framework (e.g., Council of Europe and Organisation for Economic Co-operation and Development).

Second, at every COP, meetings are held with parliamentary delegations from third countries, which show a constant pattern over the years. With the exception of COP 19, the MEPs usually meet with counterparts from 3 to 7 other countries. With a number of these parlia- 
mentary delegations-particularly from the US, Brazil, Japan, South Korea, Mexico and South Africa-meetings are rather common.

Third, a recent development, particularly since COP 18 , is that the EP delegation also meets increasingly with governmental representatives from third countries. For instance, at COP 23, the EP delegation met with ministers (or in some cases heads of delegations) from Russia, the US, Brazil, Japan, China, India and Australia, as well as the chief negotiator of the Alliance of Small Island States. This shows that the EP's ad locum involvement is becoming more mature as it increasingly focuses its outreach activities on the actors who actually conduct international negotiations-governments, not parliaments. Hence, rather than an evolution in the number of meetings with third country actors, it is the kind of interlocutor that recently started to strengthen the EP's ad locum involvement in UN climate negotiations (E1b).

\section{Conclusions}

This article sought to answer the following research question: what impact have the increased powers of the EP had on its involvement in UN climate diplomacy? We find evidence to support the claims that the expressed positions of the EP have grown closer to the Councils' over time (E1a) and that the EP has become more active and increasingly interacts with governmental representatives during the negotiations, thereby presenting itself as a maturing actor in the EU's climate diplomacy (E1b). However, we do not find support for the shadow of consent affecting the EP's positions or its activities at COPs. The ex ante preferences of the EP are not closer to the Council's in COPs expected to lead to a legally binding treaty (E2a). Likewise, the number, nature and intensity of the EP delegation's ad locum activities do not significantly differ between the Copenhagen, Doha and Paris COPs and COPs that are not characterized by a shadow of consent (E2b).

There are a number of ways of interpreting these findings. First, the backward shadow of consent operates across more than one COP. UNFCCC climate negotiations are rather a continuous process than a sequence of separate, annual meetings. In other words, the consent procedure does not cast its shadow on individual COPs, but rather on a multi-year negotiation process culminating in a COP where a treaty is ultimately adopted. Second, the EP and Council share broadly similar preferences on climate change making the EP unlikely to use its veto. Here we suggest that the politicization of climate change at the global level has increased the perceived need for unity at EU level as evinced by the one-voice rhetorical device post-Copenhagen that sought to depoliticize the issue to reduce conflict amongst the EU's institutions, thereby signaling the EU's unity of purpose to external actors (also see Schreurs, 2016). Third, and relatedly, we see the EP seeking to be a reliable partner with a desire to secure a progressive international climate deal, in line with the traditional approach of the EP (Burns, 2017). The ACTA and SWIFT rejections imply that where the EP feels it has been ignored or excluded, and where there is potentially direct impact of agreements upon citizens' rights the patterns of behaviour may be different. Hence the impacts of parliamentarization and politicization are likely to vary between policy fields. Comparing the EP's involvement in international negotiations across a range of policies may reveal different patterns and is thus a promising future research agenda.

Our findings also have implications for our understanding of the role parliaments can play in international negotiations, a relatively understudied topic. It was beyond the scope of this article to investigate the implications of the parliamentary preferences and activities. A future project could investigate whether the participation of parliamentarians in international negotiations result in changes in the way other actors behave, and/or in the substantive content of international agreements. Likewise, the EP's impact on the outcome of international negotiations, as well as the possible use of the EP delegation by the Commission and the Council as part of the overall EU climate diplomacy arrangement are interesting questions to be examined in future research on the role of the EP in the EU's external relations. Overall our article demonstrates that the relationship between formal parliamentary empowerment and actual behaviour is complex and only through systematic careful analysis can we uncover patterns in parliamentary involvement.

\section{Acknowledgments}

This work was supported by the Fonds de la Recherche Scientifique (FNRS) under Grant T.0064.19. The authors also thank Thomas Laloux for valuable research assistance and the editors and anonymous reviewers for constructive feedback. Thanks are also due for helpful and constructive comments to participants of the panel on 'Power without Influence? Explaining the Impact of the EP beyond Legislation' at the European Consortium for Political Research Standing Group on the European Union Conference in Paris 2018, to the participants of the panel 'Shaping EU Climate Policy and Diplomacy' at the European Union in International Affairs Conference in Brussels 2018 and to fellow participants at a workshop on 'The New Politics of EU External Relations: Consequences of Parliamentarization and Politicization', held at the Centre of European Research University of Gothenburg (CERGU) in 2017.

\section{Conflict of Interests}

The authors declare no conflict of interests.

\section{References}

Biedenkopf, K. (2015). The European Parliament in EU external climate governance. In S. Stavridis \& D. Irrera 
(Eds.), The European Parliament and its international relations (pp. 92-108). Abingdon: Routledge.

Burns, C. (2013). The European Parliament: Still the EU's environmental champion? In A. Jordan \& C. Adelle (Eds.), Environmental policy in the European Union (3rd ed., pp. 132-152). London: Earthscan.

Burns, C. (2017). The European Parliament and climate change: A constrained leader? In R. Wurzel, J. Connelly, \& D. Liefferink (Eds.), The European Union in international climate change politics: Still taking a lead? (pp. 52-65). London: Routledge.

Burns, C., \& Carter, N. (2010). The European Parliament and climate change: From symbolism to heroism and back again. In R. Wurzel \& J. Connelly (Eds.), The EU as a leader in international climate change politics (pp. 58-73). London: Routledge.

Burns, C., Carter, N., Davies, G., \& Worsfold, N. (2013). Still saving the Earth? The European Parliament's environmental record. Environmental Politics, 22(6), 935-954.

Carter, N. (2018). The politics of the environment (3rd ed.). Cambridge: Cambridge University Press.

Council of the European Union. (2008). Council conclusions on preparations for the 14th session of the Conference of the Parties (COP 14) to the United Nations Framework Convention on Climate Change (UNFCCC) and the 4th session of the meeting of the parties to the Kyoto Protocol (CMP 4) (Poznań, 1 to 12 December 2008) (2898th Environment Council meeting Report). Brussels: Council of the European Union.

Council of the European Union. (2009). Council Conclusions on EU position for the Copenhagen Climate Conference (7-18 December 2009) (2898th Environment Council meeting Report). Brussels: Council of the European Union.

Council of the European Union. (2015). Council conclusions on the preparations for the 21st session of the Conference of the Parties (COP 21) to the United Nations Framework Convention on Climate Change (UNFCCC) and the 11th session of the meeting of the parties to the Kyoto Protocol (CMP 11) (Paris, 30 November-11 December 2015) (12165/15). Brussels: Council of the European Union.

De Wilde, P. (2011). No polity for old politics? A framework for analyzing the politicization of European integration. Journal of European Integration, 33(5), 559-575.

Delreux, T. (2011). The EU as international environmental negotiator. Surrey: Ashgate.

Delreux, T., \& Kerremans, B. (2010). How agents weaken their principals' incentives to control: The case of EU negotiators and EU member states in multilateral negotiations. Journal of European Integration, 32(4), 357-374.

Dür, A. (2006). Assessing the EU's role in international trade negotiations. European Political Science, 5(4), 362-376.

Earth Negotiations Bulletin. (2015). Summary of the
Copenhagen Climate Change Conference: 7-19 December 2009. International Institute for Sustainable Development, 12(459).

European Parliament. (2007). European Parliament resolution of 15 November 2007 on limiting global climate change to 2 degrees Celsius: The way ahead for the Bali Conference on Climate Change and beyond (COP 13 and COP/MOP3) (B6-0432/2007). Brussels: European Parliament.

European Parliament. (2009). European Parliament resolution of 25 November 2009 on the EU strategy for the Copenhagen Conference on Climate Change (COP 15) (B7-0141/2209). Brussels: European Parliament.

European Parliament. (2010a). European Parliament resolution of 10 February 2010 on the outcome of the Copenhagen Conference on Climate Change (COP 15) (P7_TA[2010]0019). Brussels: European Parliament.

European Parliament. (2010b). European Parliament resolution of 25 November 2010 on the Climate Change Conference in Cancun (COP16) (P7_TA[2010]0442). Brussels: European Parliament.

European Parliament. (2011). European Parliament resolution of 16 November 2011 on the Climate Change Conference in Durban (COP17) (P7_TA[2011]0504). Brussels: European Parliament.

European Parliament. (2012). European Parliament resolution of 22 November 2012 on the Climate Change Conference in Doha, Qatar (COP 18) (P7_TA[2012]0452). Brussels: European Parliament.

European Parliament. (2013). European Parliament resolution of 23 October 2013 on the Climate Change Conference in Warsaw, Poland (COP 19) (P7_TA[2013]0443). Brussels: European Parliament.

European Parliament. (2014). European Parliament resolution of 26 November 2014 on the UN Climate Change Conference: COP 20 in Lima, Peru (1-2 December 2014) (P8_TA[2014]0063). Brussels: European Parliament.

European Parliament. (2015). European Parliament resolution of 4 October 2015 on towards a new international climate agreement in Paris (2015/112 [INI]) (P8_TA[2015]0359). Brussels: European Parliament.

European Parliament. (2016). European Parliament resolution of 6 October 2016 on the implementation of the Paris Agreement and the 2016 UN Climate Change Conference in Marrakesh, Morocco (COP22) (2016/2814[RSP]) (P8_TA[2016]0383). Brussels: European Parliament.

European Parliament. (2017). European Parliament resolution of 4 October 2017 on the UN Climate Change Conference in Bonn, Germany (COP23) (P8_TA[2017]0380). Brussels: European Parliament.

European Union. (2012). Consolidated version of the Treaty on the Functioning of the European Union (OJ C 326). Brussels: European Parliament.

Hovi, J., \& Skodvin, T. (Eds.). (2016). Climate governance and the Paris Agreement [Thematic Issue]. Politics 
and Governance, 4(3), 111-223.

Jančić, D. (2016). World diplomacy of the European Parliament. The Hague Journal of Diplomacy, 11(2/3), 121-143.

Judge, D. (1992). Predestined to save the earth: The Environment Committee of the European Parliament. Environmental Politics, 1(4), 186-212.

McCright, A., \& Dunlap, R. (2011). The politicization of climate change and polarization in the American public's views of global warming, 2001-2010. The Sociological Quarterly, 52(2), 155-194.

Meissner, K. (2016). Democratizing EU external relations: The European Parliament's informal role in SWIFT, ACTA, and TTIP. European Foreign Affairs Review, 21(2), 269-288.

Monar, J. (2010). The rejection of the EU-US SWIFT interim agreement by the European Parliament: A historic vote and its implication. European Foreign Affairs Review, 15(2), 143-151.

Onderco, M. (2018). Parliamentarians in government delegations: An old question still not answered. Cooperation and Conflict, 53(3), 411-428.

Pepermans, Y., \& Maeseele, P. (2016). The politicization of climate change: Problem or solution? WIRES Climate Change, 7(4), 478-485.

Raffaeli, R. (2013). Horizontal review between international organizations: A reply to Abigail C. Deshman. The European Journal of International Law, 24(4), 1194-1200.

Riddervold, M., \& Rosén, G. (2015). Beyond intergovernmental cooperation: The influence of the European Parliament and the Commission on EU foreign and security policies. European Foreign Affairs Review, 20(3), 399-418.

Ripoll Servent, A. (2013). Holding the European Parliament responsible: Policy shift in the data retention directive from consultation to codecision. Journal of European Public Policy, 20(7), 927-987.

Ripoll Servent, A. (2014). The role of the European Parliament in international negotiations after Lisbon. Journal of European Public Policy, 21(4), 568-586.
Ripoll Servent, A. (2018). The European Parliament. London: Palgrave Macmillan.

Rosén, G. (2015). EU confidential: The European Parliament's involvement in EU security and defence policy. Journal of Common Market Studies, 53(2), 383-398.

Rosén, G. (2016). A match made in heaven? Explaining patterns of cooperation between the Commission and the European Parliament. Journal of European Integration, 38(4), 409-424.

Rosén, G., \& Raube, K. (2018). Influence beyond formal powers: The parliamentarisation of European Union security policy. The British Journal of Politics and International Relations, 20(1), 69-83.

Schreurs, M. (2016). The Paris Climate Agreement and the three largest emitters: China, the United States, and the European Union. Politics and Governance, 4(3), 219-223.

Stavridis, S., \& Irrera, D. (Eds.). (2015). The European Parliament and its international relations. Abingdon: Routledge.

Thym, D. (2008). Parliamentary involvement in European international relations. In M. Cremona \& B. de Witte (Eds.), EU foreign relations law: Constitutional fundamentals (pp. 201-232). Portland: Hart Publishing.

Urban, M. (2018). Interinstitutional agreements' influence on the competences of the EP in the procedure for concluding international agreements. Paper presented at the workshop Challenges and Opportunities for EU Parliamentary Democracy: Brexit and beyond, Brussels, Belgium.

Van den Putte, L., De Ville, F., \& Orbie, J. (2015). The European Parliament as an international actor in trade: From power to impact. In S. Stavridis \& D. Irrera (Eds.), The European Parliament and its international relations (pp. 52-69). Abingdon: Routledge.

Van Hecke, S., \& Wolfs, W. (2015). The European Parliament and European foreign policy. In K. Jørgensen, A. Aarstad, E. Drieskens, K. Laatikainen, \& B. Tonra (Eds.), The SAGE handbook of European foreign policy (pp. 291-305). London: SAGE.

\section{About the Authors}

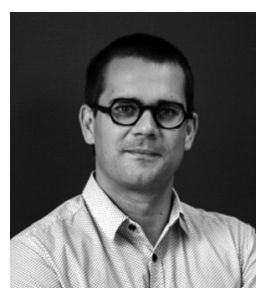

Tom Delreux is a Professor of Political Science and EU politics at the University of Louvain (Louvainla-Neuve) and a Visiting Professor at the College of Europe (Bruges). His research interests include the EU's external relations, EU environmental policy, EU institutions and international environmental politics.

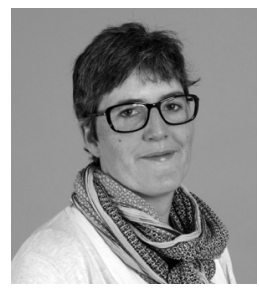

Charlotte Burns is Professor of Politics at the University of Sheffield. Her background is in studying EU decision-making and EU environmental politics and policy, with a specific focus upon the EP, upon which she has published extensively. More recently Professor Burns has been analysing the implications of Brexit for UK and EU environmental policy and the impact of the global financial and economic crisis for European environmental policy. 